\title{
OPTIMALISASI PEMANFAATAN DATA ARAH DAN KECEPATAN ANGIN POLA MONSUNAL UNTUK KAJIAN PEMETAAN POTENSI ENERGI ANGIN DI WILAYAH NUSA TENGGARA BARAT
}

\author{
Abdul Hamid Al Habib ${ }^{1}$, Kholis Nur Cahyo ${ }^{2}$, Prasetyo Umar Firdianto ${ }^{3}$, Paulus Agus \\ Winarso ${ }^{4}$ \\ ${ }^{1,2,3,4}$ Program Studi Meteorologi Sekolah Tinggi Meteorologi Klimatologi dan Geofisika \\ Jl. Perhubungan I-Pondok Betung, Tanggerang Selatan 15221 \\ E-mail: abdulhamidalhabib96@gmail.com
}

\begin{abstract}
The National Institute of Aeronautics and Space (LAPAN) as of July 182017 released data that from 166 locations studied, there were 35 locations that had good wind potential with wind speeds above 5 meters per second at a height of 50 meters. Regions that have good wind speeds, one of which is West Nusa Tenggara (NTB). West Nusa Tenggara is an area that is crossed by monsunal wind patterns and is an island surrounded by beaches so that the West Nusa Tenggara region receives high winds. This can potentially be installed by wind turbines to be able to convert wind energy into electricity. Wind direction and speed data obtained from satellites are processed into average data then adjusted to the wind speed threshold that can rotate wind turbines. The results obtained are mapped using the GrADS application to determine the potential area for horizontal axis type wind turbine installation at a height of 10 meters based on monsunal pattern direction and wind speed. This study will provide recommendations on potential areas of wind energy and predictions of electrical power that will be generated from the use of these maps. The results of the study show that the West Nusa Tenggara region by utilizing wind energy can create electricity in a year totaling 14067.4026 $k W h$.
\end{abstract}

Keywords: Speed of Wind, Monsunal Wind Patterns and Wind Turbines

\begin{abstract}
Abstrak: Lembaga Penerbangan dan Antariksa Nasional (LAPAN) per 18 Juli 2017 merilis data bahwa dari 166 lokasi yang diteliti, terdapat 35 lokasi yang mempunyai potensi angin yang bagus dengan kecepatan angin diatas 5 meter perdetik pada ketinggian 50 meter. Daerah yang mempunyai kecepatan angin bagus tersebut, salah satunya adalah wilayah Nusa Tenggara Barat (NTB). Nusa Tenggara Barat merupakan wilayah yang dilintasi oleh pola angin monsunal dan merupakan pulau yang dikelilingi oleh pantai sehingga wilayah Nusa Tenggara Barat menerima hembusan angin yang cukup tinggi. Hal ini dapat berpotensi untuk dipasang turbin angin untuk dapat mengkonversi energi angin menjadi energi listrik. Data arah dan kecepatan angin yang diperoleh dari satelit diolah menjadi data rata-rata kemudian disesuaikan ke dalam batas ambang kecepatan angin yang dapat memutar turbin angin. Hasil yang diperoleh tersebut dipetakan dengan menggunakan aplikasi GrADS guna menetukan wilayah yang berpotensi untuk pemasangan turbin angin jenis sumbu horizontal pada ketinggian 10 meter berdasarkan arah dan kecepatan angin pola monsunal. Penelitian ini akan memberikan rekomendasi wilayah potensi energi angin serta prediksi daya listrik yang akan dihasilkan dari pemanfaatan peta tersebut. Hasil penelitian menunjukan wilayah Nusa Tenggara Barat dengan memanfaatkan energi angin dapat menciptakan energi listrik dalam setahun berjumlah 14067.4026 kWh.
\end{abstract}

Kata kunci: Kecepattan Angin, Angin Pola Monsunal dan Turbin Angin 


\section{PENDAHULUAN}

Saat ini kebutuhan energi listrik di Indonesia semakin meningkat. Krisis listrik ini sudah sejak lama menjadi persoalan dan telah diprediksi oleh banyak ahli energi di Indonesia sejak sepuluh tahun yang lalu. Kebutuhan energi ini dapat meningkat secara eksponensial, baik ditinjau dari kapasitasnya, kualitasnya maupun ditinjau dari tuntutan distribusinya.

Konsumsi listrik di Indonesia setiap tahunnya terus meningkat sejalan dengan peningkatan pertumbuhan ekonomi nasional. Peningkatan kebutuhan listrik ini dikemudian hari yang diperkirakan dapat tumbuh rata-rata 6,5 persen per tahun hingga 2020. Konsumsi listrik Indonesia yang begitu besar akan menjadi masalah bila dalam penyediaannya tidak sejalan dengan kebutuhan. Kebutuhan pasokan energi listrik yang terus-menerus dan berkualitas menjadi tuntutan yang harus dipenuhi oleh negara.

Salah satu sumber energi alternatif yang dapat dimanfaatkan untuk membangkitkan energi listrik adalah angin. Angin yang tersedia secara bebas di alam merupakan sumber energi yang tidak ada habisnya, dapat dimanfaatkan sebagai sumber energi yang sistem konversinya bersifat ramah lingkungan.

Dalam kajian pemetaan potensi energi angin diperlukan data mengenai kecepatan angin di suatu daerah sebagai tempat pemasangan turbin angin. Perlu dilakukan kajian mengenai pemetaan pemasangan turbin angin yang akurat untuk melakukan analisa daya listrik yang dapat dihasilkan dengan energi angin di daerah tersebut.

Berdasarkan data Lembaga Penerbangan dan Antariksa Nasional (LAPAN) per 18 Juli 2017 merilis data bahwa dari 166 lokasi yang diteliti, terdapat 35 lokasi yang mempunyai potensi angin yang bagus dengan kecepatan angin diatas 5 meter perdetik pada ketinggian 50 meter. Daerah yang mempunyai kecepatan angin bagus tersebut, salah satunya adalah wilayah Nusa Tenggara Barat (NTB). Nusa Tenggara Barat merupakan wilayah yang dilintasi oleh pola angin monsunal dan merupakan pulau yang dikelilingi oleh pantai sehingga wilayah Nusa Tenggara Barat menerima hembusan angin yang cukup tinggi.

Monsun merupakan angin yang bertiup sepanjang tahun dan berganti arah dua kali dalam setahun. Ada dua ciri utama daripada 2 iklim Monsun di atas, yakni adanya perbedaan yang tegas antara musim basah (wet season) dan musim kering (dry season) yang umumnya terjadi pada periode Desember, Januari, dan februari (DJF) dan Juni, Juli dan Agustus (JJA) (Chao et al, 2001). Pada tahun 1686, Edmund Halley mengemukakan teori bahwa Monsun terjadi akibat adanya perbedaan panas antara daratan dengan lautan sebagai hasil dari zenithal march matahari (Chang, 1984).

Monsun merupakan sistem sirkulasi regional yang mempunyai variasi musiman, dengan adanya gerak semu matahari terhadap bumi secara periodik di belahan bumi utara dan selatan menyebabkan angin di wilayah Indonesia sangat dipengaruhi oleh adanya perbedaan sel tekanan tinggi dan sel tekanan rendah di benua Asia dan Australia secara bergantian, Ramage (1971) dan (Prawirowardoyo, 1996). Monsun di Indonesia adalah bagian dari monsun Asia dan Australia.

Angin Monsun Asia berlangsung pada saat musim dingin di belahan bumi utara khatulistiwa, umumnya terjadi pada bulan Oktober hingga April dan puncaknya pada bulan Desember, Januari, Februari, angin monsun bertiup dari daerah Siberia menuju benua Australia. Pada periode ini daerah-daerah di Indonesia yaitu daerah yang berada di sekitar Sumatera bagian selatan, Jawa, Bali, Lombok, Nusa Tenggara sampai dengan Papua, angin monsun bertiup dari Barat ke Timur. Daerah ini disebut monsun dingin dari belahan bumi utara ini dinamakan monsun barat dan musimnya disebut musim monsun barat. Sedangkan daerah yang mencakup sebagian besar Sumatera dan Kalimantan Barat, angin monsun datang 
dari arah timur laut, angin monsun di daerah ini disebut monsun timur laut dan musimnya diberi nama musim monsun timur laut (Prawirowardoyo, 1996).

Angin Monsun Australia merupakan kondisi kebalikan dari monsun barat, yang terjadi antara bulan April hingga Oktober saat matahari berada di belahan bumi utara, menyebabkan benua Australia mengalami musim dingin, sehingga bertekanan tinggi. Sedangkan benua Asia lebih panas, sehingga tekanannya rendah. Menurut hukum Buys Ballot, angin akan bertiup dari daerah bertekanan tinggi ke daerah bertekanan rendah, sehingga angin bertiup dari benua Australia menuju benua Asia, dan karena menuju utara khatulistiwa/equator, maka angin akan dibelokkan ke arah kanan.

\section{METODE PENELITIAN}

\subsection{Lokasi Penelitian}

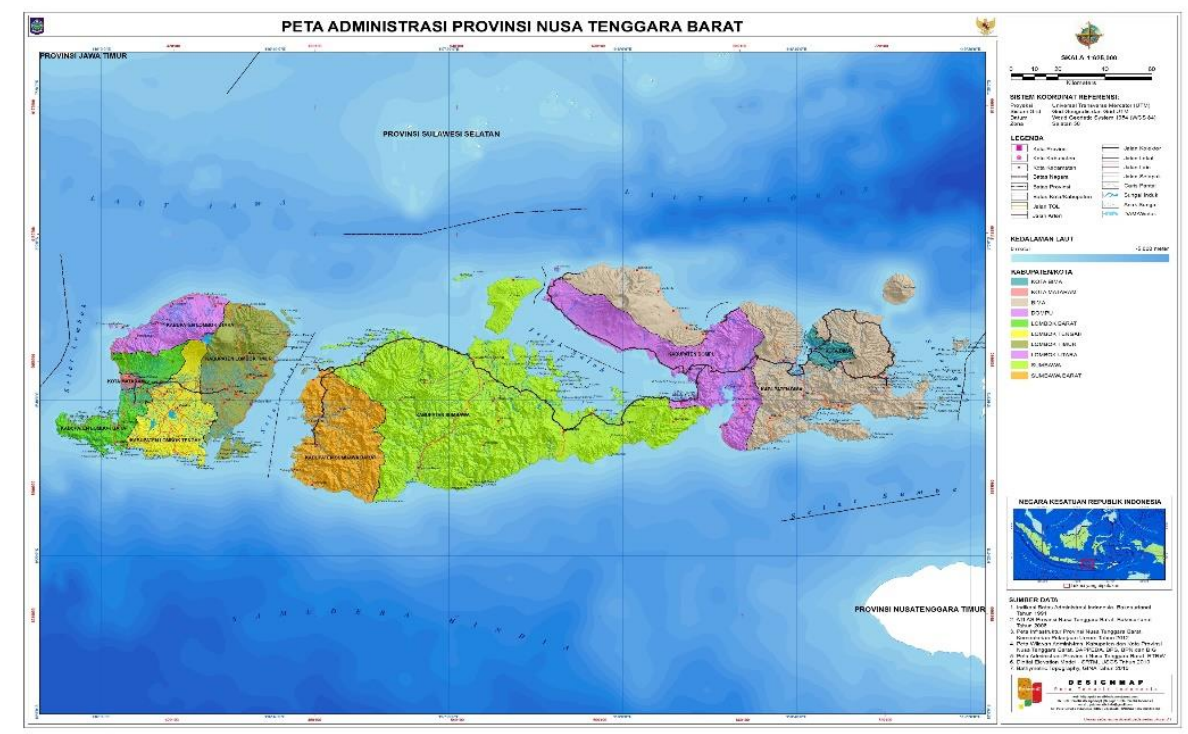

Gambar 1. Peta Provinsi Nusa Tenggara Barat (sumber : google.com)

Nusa Tenggara Barat merupakan salah satu provisi yang terletak di bagian barat Kepulauan Nusa Tenggara. Provinsi ini beribukota di Mataram dan memiliki 10 Kabupaten/Kota. Nusa Tenggara Barat berbatasan langsung dengan Laut Jawa dan Samudera Hindia. Nusa Tenggara Barat terdiri dari Pulau Lombok dan Pulau Sumbawa, memiliki luas wilayah 20.153,15 km2. Lokasi yang dipilih dalam penelitian ini yakni pada koordinat $115^{\circ} 46^{\prime}-119^{\circ} 5^{\prime}$ Bujur Timur dan $8^{\circ} 10^{\prime}-9^{\circ} \mathrm{g} 5^{\prime}$ Lintang Selatan yang mencangkup seluruh wilayah provinsi Nusa Tenggara Barat.

\subsection{Data}

Data yang digunakan dalam penelitian ini adalah data rata-rata bulanan data komponen $U$ dan $\mathrm{V}$ serta data kecepatan angin permukaan ketinggian 10 meter selama sepuluh tahun, terhitung sejak april 2007 hingga april 2017 dengan resolusi spasial $0,25^{\circ} \times 0,25^{\circ}$. Data tersebut diperoleh dari citra satelit yang kemudian diunduh melalui http://apps.ecmwf.int/datasets/data/interim-full-moda/levtype $=s f c /$. 


\subsection{Metode}

Tahapan awal yang dilakukan dalam penelitian ini ialah dengan merata-ratakan data angin komponen $\mathrm{U}$ dan $\mathrm{V}$ berdasarkan perioda monsun. Periode monsun Asia data dirata_ratakan pada bulan Oktober, November, Desember, Januari, Febuari, Maret dan April. Untuk monsun Australia data dirata-ratakan pada bulan April, Mei, Juni, Juli, Agustus, September dan Oktober selama sepuluh tahun, kemudian dipetakan menggunakan perangkat lunak GrADS guna mengetahui rata-rata arah datangnya angin pada masing-masing perioda monsunal. Periode puncak musim penghujan yaitu Desember, Januari, Februari dan puncak musim kemarau Juni, Juli, Agustus selama sepuluh tahun dipetakan menggunakan perangkat lunak GrADS. Hal tersebut dapat digunakan untuk mengetahui jenis turbin angin yang sesuai dengan wilayah penelitian.

Tahap selanjunya ialah mengekstrak data tersebut menggunakan perangkat lunak panoply, setelah diekstrak data tiap-tiap grid tersebut kemudian dirata-ratakan sehingga diperoleh data akhir berupa data kecepatan angin rata-rata selama 10 tahun. Data tersebut kemudian difilter ke dalam lima peringkat grid-grid dengan rata-rata kecepatan angin paling tinggi. Setelah difilter, data tersebut dicatat menggunakan aplikasi pengolah angka yang selanjutnya dipetakan untuk menghasilkan peta lokasi potensi untuk digunakan sebagai pembangunan turbin angin untuk mengatasi krisis listrik di wilayah tersebut. Selanjutnya data rata-rata kecepatan angin pada beberapa grid tersebut kemudian dikonversikan ke dalam bentuk watt menggunakan persamaan berikut :

\subsubsection{Perhitungan daya turbin angin}

$$
\text { Pturbin }=0,5 \times \rho \times A \times v^{3}
$$

Dimana : Pturbin : Daya listrik yang dihasilkan turbin (watt)

$$
\begin{array}{cl}
\rho & : \text { kerapatan udara }(\mathrm{kg} / \mathrm{m} 3) \\
\mathrm{A} & : \text { luas penampang sapuan turbin }(\mathrm{m}) \\
\mathrm{v} & : \text { kecepatan angin }(\mathrm{m} / \mathrm{s})
\end{array}
$$

Rumus tersebut merupakan persamaan daya turbin ideal tanpa dipengaruhi rendamen/efisiensi. Luas penampang sapuan turbin angin didapat dari persamaan $A=\pi r 2$. Sedangkan tekanan udara lokal diasumsikan sebesar 1010.0 mbar dan temperatur udara $26.9^{0} \mathrm{C}$ sehingga

$$
\rho=1.2929 \times \frac{273}{T} \times \frac{P}{760}\left(\frac{K g}{m 3}\right)
$$

$$
\begin{aligned}
\text { Dimana : } & \rho: \text { kerapatan udara }(\mathrm{kg} / \mathrm{m} 3) \\
\mathrm{T} & : \text { suhu }(\text { Kelvin }) \\
\mathrm{P} & : \text { tekanan udara }(\mathrm{mm} \mathrm{hg})
\end{aligned}
$$

\subsubsection{Perhitungan daya listrik keluaran generator Daya lisrik yang dihasilkan dipengaruhi} oleh beberapa faktor, yakni :

a. Kerugian akibat gesekan udara yang tergantung pada rakitan sayap turbin angin. Kerugian ini termasuk rendamen aerodinamika yang besarnya berkisar antara 0,3 sampai 0,8

b. Kerugian akibat gesekan bantalan yang tergantung pada rakitan bantalan beban dan pelumas. Semua itu dimasukkan ke dalam rendamen mekanik yang nilainya sebesar 0,9

c. Kerugian elektro-mekanik, bila energi angin diubah menjadi energi listrik. Kerugian ini termasuk rendamen dynamo sebesar 0,5

d. Kerugian pemakaian baterai atau efisiensi baterai yang berkisar antara 0,85 hingga 0,9 
Keempat rendamen tersebut dimasukkan dalam perhitungan, maka daya yang dapat dihasilkan oleh generator dapat dihitung dengan persamaan

$$
\begin{gathered}
\text { Pturbin }=0,5 \times \eta \operatorname{tr} \times \eta g \times \eta b \times \rho \times A \times v 3 \\
\text { Dimana : nilai efisiensi transmisi }(\eta \operatorname{tr})=0,9 \\
\text { nilai efisiensi generator }(\eta g)=0,5 \\
\text { nilai efisiensi baterai }(\eta b)=0,9
\end{gathered}
$$

2.3.3. Perhitungan energi listrik keluaran generator Energi sesaat yang dihasilkan oleh generator dihitung dengan persamaan

$$
E g=P g . t
$$

Dimana : Eg : energi listrik

Pg : daya listrik

$\mathrm{t}$ : waktu

\section{HASIL PENELITIAN DAN PEMBAHASAN}

\subsection{Kajian Rata-rata Monsun Asia dan Australia}
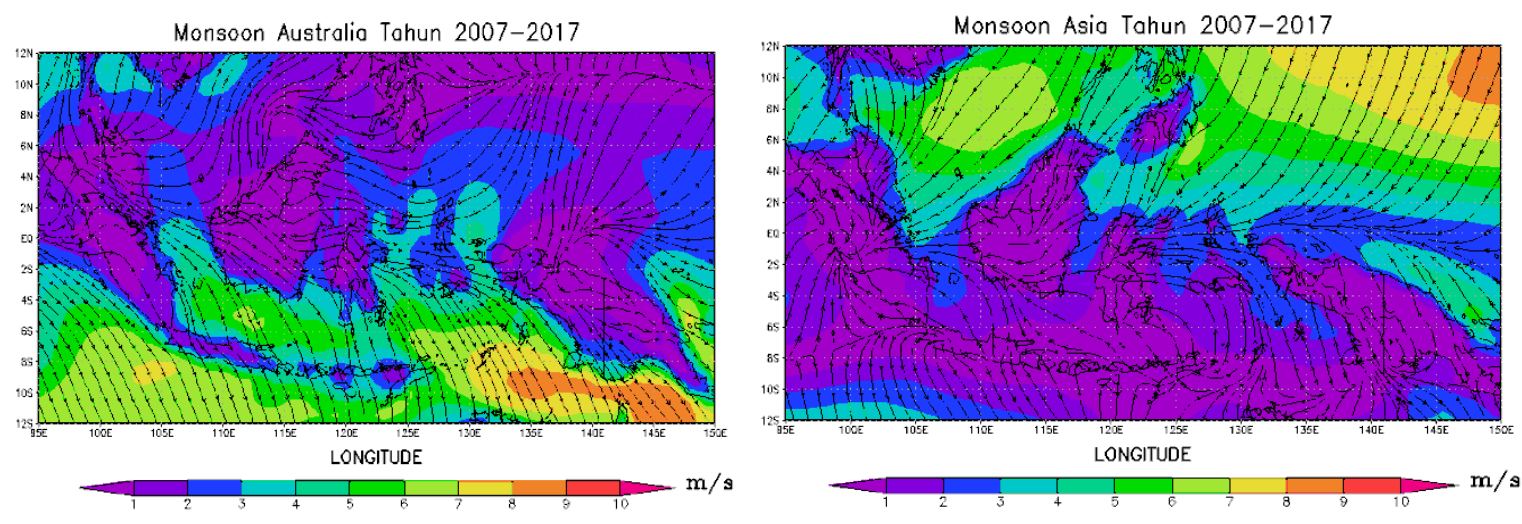

Gambar 2. Hasil output dari GrADS monsun Asia dan Australia Untuk Indonesia. 

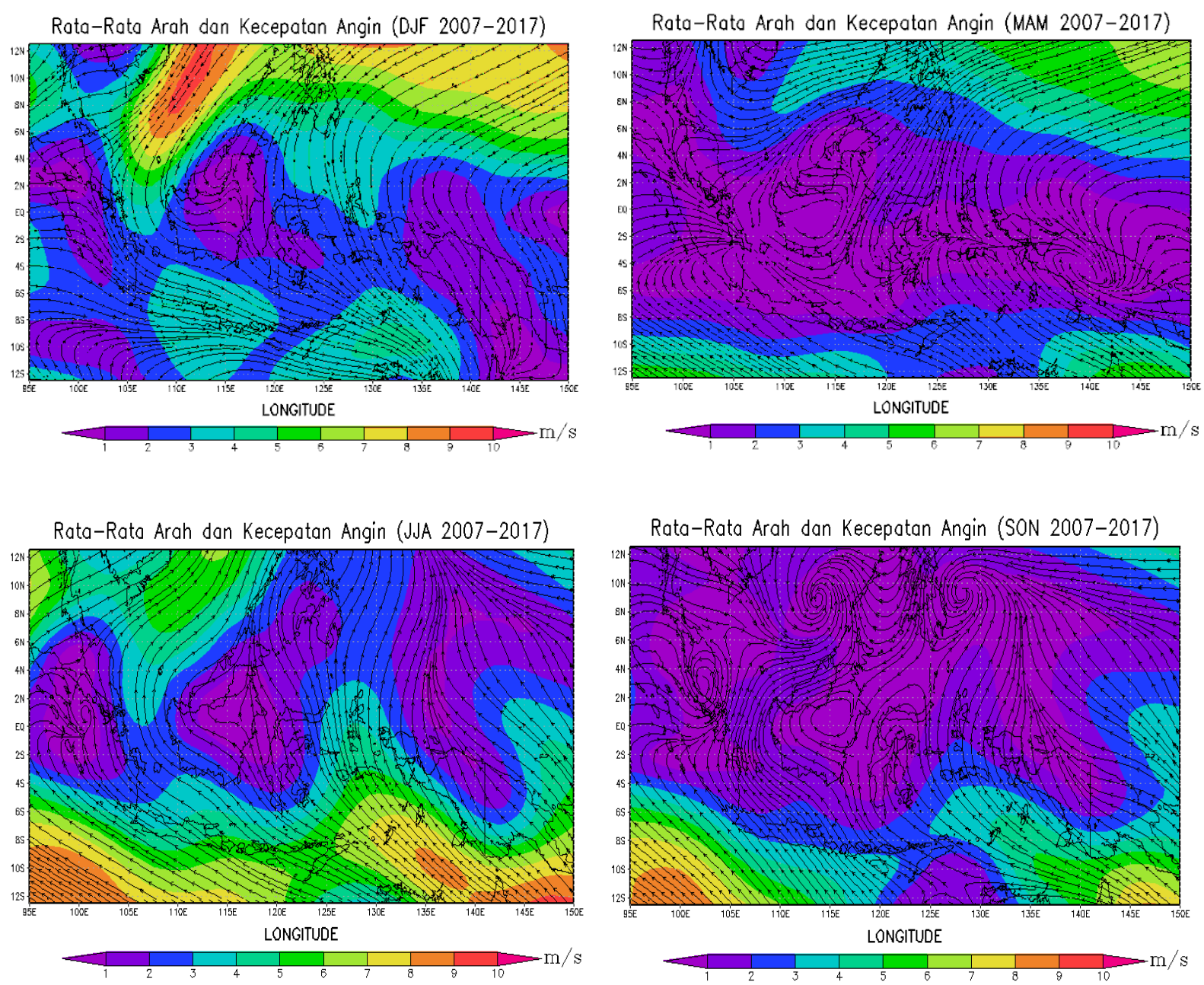

Gambar 3. Hasil output dari GrADS pola angin monsunal Indonesia

Berdasarkan hasil output dari GrADS pada perioda monsun Asia terlihat bahwa rata-rata selama 10 tahun terakhir angin berhembus dari arah timur laut kemudian sebagian besar wilayah di Indonesia dibelokkan ke arah tenggara. Untuk lokasi pada penelitian ini terlihat rata-rata arah angin berhembus dari arah barat kemudian dibelokan ke arah tenggara. Namun untuk wilayah provinsi Nusa Tenggara Barat terlihat bahwa kecepatan angin ketika monsun Asia lebih kecil ketika monsun Australia.

Kemudian monsun Australia terlihat dari peta di atas dalam 10 tahun terakhir arah datangnya angin berhembus dari arah tenggara kemudian dibelokan menuju arah timur laut yang berkebalikan dengan periode monsun Asia. Namun terdapat pula sebagian kecil wilayah di Indonesia yang mengalami pembelokan angin yang tidak begitu tajam yakni angin yang berhembus dari arah tenggara kemudian dibelokan menuju arah utara. Pada lokasi penelitian terlihat bahwa arah datangnya angin pada umumnya berasal dari arah tenggara. 

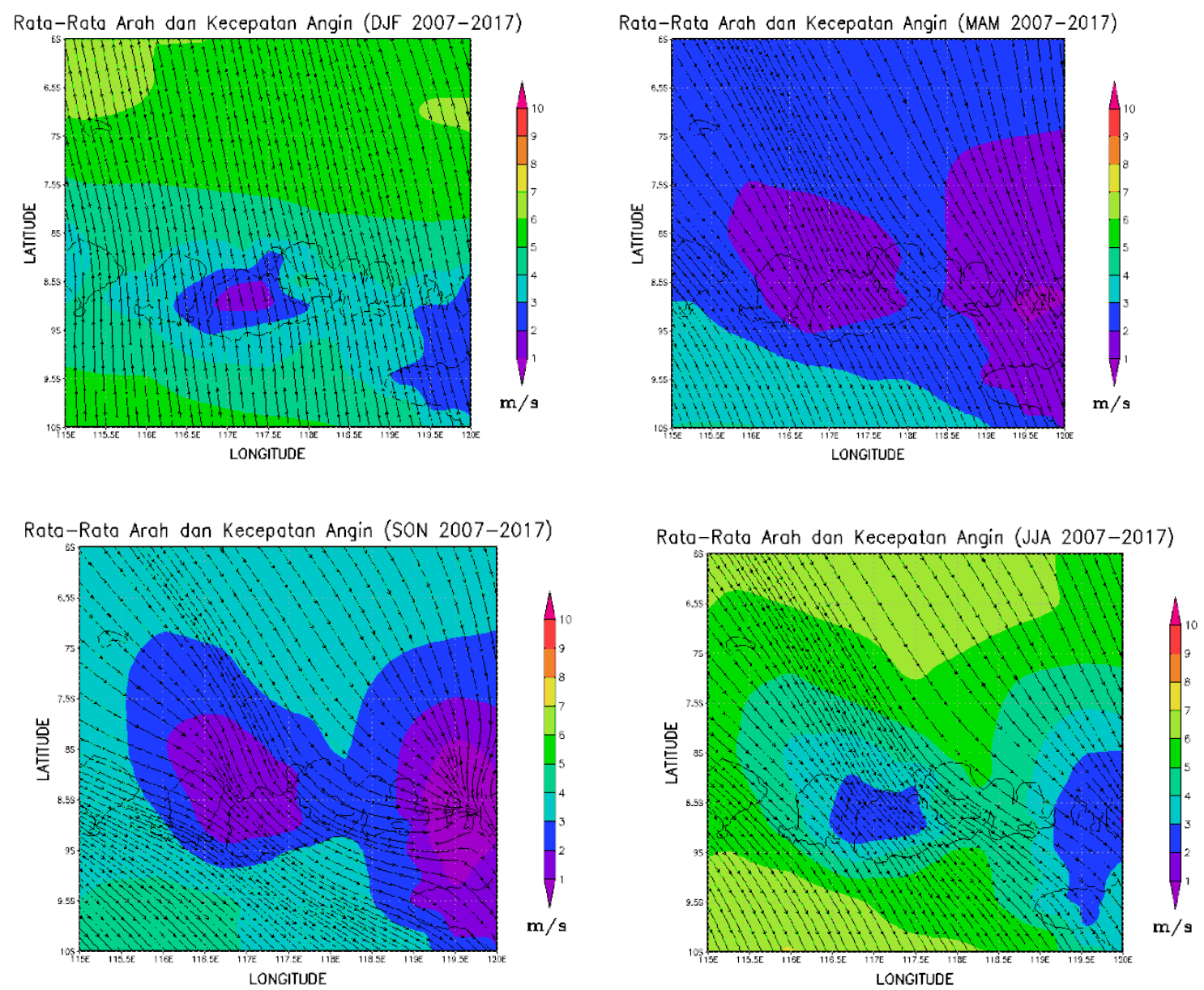

Gambar 4. Hasil output dari GrADS pola angin monsunal untuk Nusa Tenggara Barat

Berdasarkan hasil output dari GrADS pada puncak musim penghujan (periode bulan desember, januari, februari) pola angin di wilayah Jawa, Bali hingga Nusa Tenggara memiliki kecepatan yang lebih tinggi dari pada bulan-bulan yang lain, bertiup dari arah Barat Laut dengan kecepatan berkisar antara 10-14 knots. Akan tetapi pada puncak musim kemarau (periode bulan januari, februari, maret) pola angin di wilayah Jawa, Bali hingga Nusa Tenggara memiliki kecepatan yang lebih tinggi dari pada bulan-bulan yang lain, bertiup dari arah Timur Tenggara dengan kecepatan berkisar 12-16 knots.

Secara klimatologis dan normalnya pola tekanan udara di ketika monsun Australia lebih tinggi dibandingkan ketika monsun Asia. Selisih tekanan udara yang cukup besar merupakan faktor yang meningkatkan dan menguatkan tarikan massa udara dan kecepatan angin di sekitar Indonesia terutama di sebelah Selatan Khatulistiwa Indonesia (Jawa, Bali dan Nusa Tenggara).

Hal ini disebabkan oleh sifat massa udara yang bergerak dari daerah yang memiliki tekanan udara yang tinggi menuju daerah yang memiliki tekanan lebih rendah. Semakin tinggi selisih tekanan udara antara dua daerah, maka kecepatan gerak massa udara juga akan semakin tinggi.

Berdasarkan analisis tersebut, penulis merekomendasikan pemasangan jenis turbin angin sumbu vertikal sehingga angin dari berbagai arah dapat memutar turbin angin. Turbin yang baik digunakan di wilayah penelitian adalah turbin yang dapat menerima angin dari segala 
arah selain itu juga mampu bekerja pada angin dalam kecepatan yang rendah salah satunya Turbin Angin Sumbu Vertikal (TASV). Turbin ini memiliki efisiensi yang lebih kecil dibandingkan dengan turbin angin sumbu horizontal.

\subsection{Perhitungan Potensi Daya dan Energi Listrik}

Dengan jari-jari turbin sebesar $2 \mathrm{~m}$, didapat daya dan energi listrik pada beberapa lokasi potensial Energi angin di Nusa Tenggara Barat sebagai berikut:

Tabel 1. Tabel Rata-rata Arah dan Kecepatan Angin Sepuluh Tahun dan Lokasi Potensi Energi Angin di Nusa Tenggara Barat

\begin{tabular}{|c|c|c|c|c|c|c|}
\hline \multicolumn{7}{|c|}{ DESEMBER-JANUARI-FEBRUARI } \\
\hline \multirow{2}{*}{ lat } & \multirow{2}{*}{ Ion } & \multirow{2}{*}{$V(\mathrm{~m} / \mathrm{s})$} & \multirow{2}{*}{ Arah (derajat) } & \multirow{2}{*}{$P$ (watt) } & \multirow{2}{*}{$E(k W h)$} & Energi Listrik dalam \\
\hline & & & & & & satu tahun (kWh) \\
\hline-10 & 112.5 & 3.597337786 & 85 & 10.08328658 & 4.083731066 & 1490.561839 \\
\hline-10 & 115 & 3.369316137 & 90 & 8.284832611 & 3.355357208 & 1224.705381 \\
\hline-10 & 117.5 & 3.052025841 & 101 & 6.157764444 & 2.4938946 & 910.2715289 \\
\hline-10 & 120 & 2.915977922 & 105 & 5.370455801 & 2.1750346 & 793.8876288 \\
\hline-7.5 & 112.5 & 3.886762185 & 100 & 12.7181036 & 5.150831958 & 1880.053665 \\
\hline-7.5 & 115 & 3.734478667 & 105 & 11.28102083 & 4.568813435 & 1667.616904 \\
\hline-7.5 & 117.5 & 3.457290935 & 110 & 8.9508903 & 3.625110571 & 1323.165359 \\
\hline-7.5 & 120 & 3.052378037 & 110 & 6.159896459 & 2.494758066 & 910.5866941 \\
\hline \multicolumn{5}{|c|}{ Energi total } & 27.9475315 & 10200.849 \\
\hline \multicolumn{7}{|c|}{ MARET-APRIL-MEI } \\
\hline \multirow{2}{*}{ lat } & \multirow{2}{*}{ Ion } & \multirow{2}{*}{$V(\mathrm{~m} / \mathrm{s})$} & \multirow{2}{*}{ Arah (derajat) } & \multirow{2}{*}{$P$ (watt) } & \multirow{2}{*}{$E(k W h)$} & Energi Listrik dalam \\
\hline & & & & & & satu tahun (kWh) \\
\hline-10 & 112.5 & 2.472156019 & 300 & 3.27254841 & 1.325382106 & 483.7644687 \\
\hline-10 & 115 & 2.658545818 & 295 & 4.06996712 & 1.648336683 & 601.6428895 \\
\hline-10 & 117.5 & 2.603478304 & 290 & 3.822261015 & 1.548015711 & 565.0257345 \\
\hline-10 & 120 & 2.504343513 & 285 & 3.402045759 & 1.377828532 & 502.9074143 \\
\hline-7.5 & 112.5 & 0.855025837 & 310 & 0.135392986 & 0.054834159 & 20.01446821 \\
\hline-7.5 & 115 & 0.798506403 & 305 & 0.110279214 & 0.044663082 & 16.30202477 \\
\hline-7.5 & 117.5 & 0.642419192 & 305 & 0.057426715 & 0.02325782 & 8.489104121 \\
\hline-7.5 & 120 & 0.800101685 & 315 & 0.110941493 & 0.044931305 & 16.39992624 \\
\hline \multicolumn{5}{|c|}{ Energi total } & 6.067249398 & 2214.54603 \\
\hline \multicolumn{7}{|c|}{ JUNI-JULI-AGUSTUS } \\
\hline \multirow{2}{*}{ lat } & \multirow{2}{*}{ Ion } & \multirow{2}{*}{$V(\mathrm{~m} / \mathrm{s})$} & \multirow{2}{*}{ Arah (derajat) } & \multirow{2}{*}{$P$ (watt) } & \multirow{2}{*}{$E(k W h)$} & Energi Listrik dalam \\
\hline & & & & & & satu tahun (kWh) \\
\hline-10 & 112.5 & 6.15749268 & 295 & 50.56734652 & 20.47977534 & 7475.118 \\
\hline-10 & 115 & 6.380745519 & 295 & 56.26945706 & 22.78913011 & 8318.03249 \\
\hline-10 & 117.5 & 6.246685088 & 295 & 52.79676221 & 21.3826887 & 7804.681374 \\
\hline-10 & 120 & 6.013318751 & 290 & 47.09785499 & 19.07463127 & 6962.240414 \\
\hline-7.5 & 112.5 & 4.723446725 & 305 & 22.82629977 & 9.244651406 & 3374.297763 \\
\hline-7.5 & 115 & 4.863836965 & 310 & 24.92272235 & 10.09370255 & 3684.201431 \\
\hline
\end{tabular}




\begin{tabular}{|c|c|c|c|c|c|c|}
\hline-7.5 & 117.5 & 4.515647738 & 310 & 19.94429178 & 8.077438173 & 2948.264933 \\
\hline-7.5 & 120 & 4.301442113 & 300 & 17.23854872 & 6.981612231 & 2548.288464 \\
\hline \multicolumn{5}{|c|}{ Energi total } & 118.1236298 & 43115.12487 \\
\hline \multicolumn{7}{|c|}{ SEPTEMBER-OKTOBER-NOVEMBER } \\
\hline \multirow{2}{*}{ lat } & \multirow{2}{*}{ Ion } & \multirow{2}{*}{$V(\mathrm{~m} / \mathrm{s})$} & \multirow{2}{*}{ Arah (derajat) } & \multirow{2}{*}{$P$ (watt) } & \multirow{2}{*}{$E(k W h)$} & Energi Listrik dalam \\
\hline & & & & & & satu tahun (kWh) \\
\hline-10 & 112.5 & 4.007385809 & 320 & 13.93933065 & 5.645428914 & 2060.581553 \\
\hline-10 & 115 & 3.743579681 & 315 & 11.36369834 & 4.602297827 & 1679.838707 \\
\hline-10 & 117.5 & 3.521601215 & 310 & 9.459735149 & 3.831192735 & 1398.385348 \\
\hline-10 & 120 & 3.332405757 & 300 & 8.015526982 & 3.246288428 & 1184.895276 \\
\hline-7.5 & 112.5 & 2.620646302 & 320 & 3.898375617 & 1.578842125 & 576.2773756 \\
\hline-7.5 & 115 & 2.425394659 & 325 & 3.090336013 & 1.251586085 & 456.8289211 \\
\hline-7.5 & 117.5 & 2.137036762 & 325 & 2.11394864 & 0.856149199 & 312.4944576 \\
\hline-7.5 & 120 & 2.205736976 & 310 & 2.324446865 & 0.94140098 & 343.6113579 \\
\hline \multicolumn{5}{|c|}{ Energi total } & 21.95318629 & 8012.912997 \\
\hline
\end{tabular}

Pada tabel diatas koordinat yang digunakan lebih disederhanakan yakni pada $7.5^{\circ}-5^{\circ} \mathrm{LU}$ dan $112.5^{\circ} \mathrm{BT}-120^{\circ} \mathrm{BT}$ agar lokasi potensi pembangunan turbin angin tidak berada di laut. Dari tabel tersebut dapat diketahui lima lokasi (grid) dengan rata-rata kecepatan angin paling tinggi pada puncak musim kemarau pada bulan JJA (juni, juli, agustus) yakni pada koordinat $(-7,5 ; 112,5)$ dengan kecepatan angin rata-rata sebesar $4.723446725 \mathrm{~m} / \mathrm{s}$. lalu pada koordinat ($7,5 ; 115)$ dengan kecepatan angin rata-rata $4.863836965 \mathrm{~m} / \mathrm{s}$. kemudian pada koordinat ($7,5 ; 117,5)$ dimana kecepatan angin rata-ratanya sebesar $4.515647738 \mathrm{~m} / \mathrm{s}$. selanjutnya pada koordinat $(-7,5 ; 120)$ dengan kecepatan angin rata-rata sebesar $4.301442113 \mathrm{~m} / \mathrm{s}$. dan pada koordinat $(-5 ; 112,5)$ dengan kecepatan angin $3.614781002 \mathrm{~m} / \mathrm{s}$.

\section{KESIMPULAN}

Kesimpulan yang diperoleh dari hasil penelitian ini adalah :

1. Pada lokasi penelitian, perputaran turbin angin bergerak menyesuaikan dengan arah datangnya angin dimana umumnya pada perioda monsun Asia angin berhembus dari utara dan berbelok ke tenggara sedangkan pada perioda monsun Australia angin berhembus dari selatan dan berbelok ke barat laut. Maka penulis merekomendasikan pemasangan jenis Turbin Angin Sumbu Vertikal (TASV) sehingga angin dari berbagai arah dapat memutar turbin angin.

2. Berdasarkan kajian data kecepatan angin dari tahun 2007 hingga 2017 , didapat 5 titik lokasi dengan kecepatan angin rata-rata lebih tinggi dari lokasi lainnya yakni : $(-7,5 ; 112,50)$, ($7,5 ; 115),(-7,5 ; 117,5),(-7,5 ; 120),(-5 ; 112,5)$. Dimana lokasi tersebut merupakan wilayah di selatan pesisir Nusa Tenggara Barat. Total energi listrik yang dihasilkan dalam setahun dari kelima lokasi adalah sebesar $63543.43 \mathrm{kWh}$ sehingga dapat membantu memenuhi kebutuhan listrik di daerah Nusa Tenggara Barat yang mengalami defisit listrik.

3. Secara klimatologis dan normalnya pola tekanan udara di ketika monsun Australia lebih tinggi dibandingkan ketika monsun Asia. Selisih tekanan udara yang cukup besar merupakan faktor yang meningkatkan dan menguatkan tarikan massa udara dan kecepatan angin di sekitar Indonesia terutama di sebelah Selatan Khatulistiwa Indonesia (Jawa, Bali 
dan Nusa Tenggara). Sehingga ketika puncak musim kemarau periode bulan DJF (desember, januari, februari) kecepatan angina dan energi yang dihasilkan paling besar daripada periode bulan-bulan lain.

\section{DAFTAR PUSTAKA}

Ryzki. (2013). Skripsi Kajian Kelayakan Potensi Energi Angin Pada Kawasan Universitas Tanjungpura Pontianak Untuk Dimanfaatkan Menjadi Energi Listrik. Fakultas Teknik Universitas Tanjung Pura.

Sugiarto. (2015). Penggunaan Data Pilot Balon untuk Kajian Potensi Pembangkit Listrik Tenaga Bayu di Pulau Bawean. Jatinangor : Bale Sawala Kampus Universitas Padjadjaran.

Tjasyono, Bayong. (2004). Klimatologi. Bandung : ITB

Tjasyono, Bayong.(1992).Klimatologi Terapan, Pionir Jaya, Bandung, 152-163.

Ali, H.A.(2013). Eksperimental comparison study for Savonius wind turbine of two \& three blandes at low wind speed. International Journal of Modern Researh IJMER., 3, 2978-2986.

Vaishali, A.V., Patil.S.A., Thakur.A.G.(2014).Optimization of Savinius rotor for wind turbine.International Journal of Advances in Engineering and Technology, .7, 12941299

www.nafiun.com/2015/02/angin-monsun-muson-musim.html (diakses pada tanggal 15 November 2018) 